\title{
Perlindungan Hukum Pembeli Apartemen Terkait Transparansi Informasi Status Hak Atas Tanah Bersama Apartemen
}

\author{
Marsella Lesmana ${ }^{1}$ dan Sri Laksmi Anindita ${ }^{2}$ \\ ${ }^{1,2}$ Magister Kenotariatan, Universitas Indonesia \\ Corresponding author. Email: marsella_lesmana@yahoo.co.id
}

Naskah diterima: 07-09-2021 revisi: 17-11-2021; disetujui: 30-11-2021

DOI: https://doi.org/10.46257/jrh.v25i2.286

\begin{abstract}
Abstrak
Pemilik satuan rumah susun atau apartemen seharusnya memiliki informasi yang cukup tentang status hak atas tanah bersama dari rumah susun pada saat melakukan pembelian. Karena jika tidak mengetahui status hak atas tanah bersamanya, pemilik apartemen akan terkejut jika harus membayar biaya yang sangat mahal untuk perpanjangan jangka waktu Hak Guna Bangunan dari tanah bersama apartemennya yang harus ditanggung oleh pemilik. Permasalahan yang akan dikaji yaitu terkait perlindungan hukum terhadap pembeli apartemen terkait transparansi informasi status hak atas tanah bersama apartemen pada saat pemasaran dilakukan oleh pelaku pembangunan dan terkait penerapan asas kebebasan berkontrak dari pihak pembeli apartemen terkait kepastian status hak atas tanah bersama apartemen pada saat perjanjian pengikatan jual beli. Penelitian ini dilakukan untuk menganalisis bentuk perlindungan konsumen terkait kewajiban pelaku pembangunan dalam hal pemberian informasi secara akurat dan tersampaikan pada saat pemasaran dan mengkaji materi muatan dalam PPJB berupa informasi kepemilikan hak yang memberikan kepastian akan kebenaran status hak atas tanah bersama apartemen. Penelitian menggunakan metode yuridis-normatif dengan pendekatan hukum positif yang berlaku pada saat ini. Hasil penelitian menunjukkan bahwa terdapat perlindungan hukum kepada masyarakat berupa hak konsumen untuk mendapatkan informasi terkait status hak atas tanah bersama apartemen dan cara penyelesaian sengketa jika tidak sesuai dengan yang diperjanjikan. Selain itu PPJB sebagai kesepakatan jual beli yang dibuat dalam akta notaris sepatutnya mencantumkan isi dari sertipikat hak atas tanah bersama apartemen antara lain nomor sertipikat, pemegang hak, status hak atas tanah, dan informasi penting lainnya di dalam bagian essentiali dari PPJB.
\end{abstract}

Kata kunci: payung hukum, informasi pemasaran, penjualan apartemen, hak konsumen.

\section{Legal Protection of Apartment Buyers}

\section{Related to Transparency of Shared Land Rights Status Information}

\begin{abstract}
The owner of the unit of flats or apartments should've sufficient information about the status of the joint land rights of the flats at the time of making the purchase. Because if the owner of the apartment doesn't know the status of land rights, will be surprised if have to pay a very expensive fee for the
\end{abstract}


period extension of the Right of Building Use that must be borne by the owner. The problems to be studied are related to legal protection for apartment buyers related to the transparency of information on the status of land rights with apartments when marketing's carried out by development actors and related to the application of the principle of freedom of contract from the apartment buyers regarding the certainty of the status of land rights with apartments at the time of the sale binding agreement. This research was conducted to analyze the form of consumer protection related to the obligations of development actors in terms of providing accurate and conveyed information at the time of marketing and reviewing the content material in PPJB in the form of information on ownership of rights which provides certainty of the correctness of the status of land rights with apartments. Research uses juridical-normative methods with positive legal approaches. The result shows that there's legal protection to the community in the form of consumers' right to get information related to the status of apartment's land rights and how to resolve disputes if its not in accordance with the promised. In addition, PPJB as a buying and selling agreement made in a notary deed should include the contents of the certificate of land rights with the apartment, including the certificate number, rights holder, land rights status, and other important information in the essentials section of the PPJB.

Keywords: legal umbrella, marketing information, apartment sales, consumer rights.

\section{Pendahuluan}

Tanah di kota-kota besar umumnya sudah sangat terbatas menyebabkan harga hunian melambung sangat tinggi. Semakin strategis letaknya, maka harga beli akan semakin tinggi sehingga hampir tidak masuk akal (Fadli, 2021). Hal tersebut dikarenakan populasi penduduk terus meningkat dari tahun ke tahun. Saat ini berdasarkan data yang bersumber dari kementerian Pekerjaan Umum dan Perumahan Rakyat (PUPR) diperkirakan backlog perumahan di Indonesia masih sangat tinggi mencapai lebih dari 11 juta orang dilihat dari jumlah kepemilikan dan lebih dari 7 juta berdasarkan jumlah penghuni (Bagus, 2020). Backlog dari jumlah penghuni diperkirakan terdiri atas 6,48 juta rumah untuk Masyarakat Berpenghasilan Rendah (MBR) non-fixed income, 1,72 juta unit rumah untuk MBR fixed income, dan 0,56 juta unit rumah untuk non-MBR (Petriella, 2020a). Namun terkait data backlog, Ketua umum Dewan Pimpinan Pusat Asosiasi Pengembang Perumahan dan Pemukiman Seluruh Indonesia (DPP Apersi), Junaidi Abdillah, menyatakan terdapat perbedaan data backlog 
antara Kementerian PUPR, data sensus kependudukan, dan lembaga lainnya sehingga sulit memprediksi jumlah pastinya (Petriella, 2020b). Dalam istilah di bidang properti, backlog artinya kondisi kesenjangan (gap) yang ada diantara jumlah rumah yang sudah terbangun dengan jumlah rumah yang rakyat butuhkan (Pinhome, 2021).

Pengertian apartemen atau rumah susun ialah tempat hunian yang dibangun bertingkat (vertikal) di atas sebidang tanah (horizontal) yang terdiri dari satuansatuan yang dapat dimiliki dan digunakan oleh masing-masing pemilik secara tersendiri (private) namun juga sekaligus dilengkapi dengan bagian-bagian, benda-benda, dan tanah secara bersama-sama (UU 20/2011). Kepemilikan apartemen meskipun sudah diatur dalam peraturan perundangan oleh pemerintah, ternyata masih kerap mengalami sengketa di tengah masyarakat. Menurut Yusuf Saipul Zamil, potensial sengketa pada rumah susun yang dibangun di atas tanah milik pemerintah dapat terjadi antara pemerintah sebagai pemilik tanah, pengembang dan masyarakat dalam hal pada saat para pemilik satuan rumah susun akan memperpanjang HGB atas tanah bersama ditolak oleh pemerintah karena HGB atas tanah bersama di atas lahan yang berstatus hak pengelolaan atas nama pemerintah dan pemerintah berencana untuk mempergunakan tanah tersebut untuk kepentingan yang lain, sehingga Yusuf Saipul Zamil berpendapat bahwa pemerintah harus menyetujui perpanjangan HGB di atas tanah HPL pada saat jatuh tempo sebagai bentuk payung hukum terhadap pemilik satuan rumah susun (Zamil, 2017:441-461). Sengketa perpanjangan HGB di atas tanah HPL untuk rumah susun juga terjadi pada perkara gugatan terhadap PT. Duta Pertiwi sebagai pelaku pembangunan Apartemen Mangga Dua Court (MDC), Badan Pertanahan Nasional (BPN), dan Pemda DKI Jakarta sebagai pemegang hak pengelolaan. Meskipun mendapatkan persetujuan perpanjangan HGB di atas tanah HPL, penghuni merasa tertipu akibat ketidaktahuan pada saat jual beli karena harus menanggung biaya perpanjangan HGB diatas HPL sebesar lebih dari Rp 4,3 milyar dibandingkan jika status tanah adalah tanah negara (HGB murni) dimana penghuni hanya membayar Rp 289 juta (Dwiwanto, 2021). Pemilik apartemen selaku konsumen 
PT Duta Pertiwi sangat dirugikan karena informasi status tanah diatas hak pengelolaan baru diketahui pada saat HGB jatuh tempo setelah sekian lama menghuni satuan rumah susun miliknya.

Pemegang HPL sendiri diberikan wewenang menurut undang-undang untuk digunakan sendiri atau dikerjasamakan dengan pihak lain melalui perjanjian dengan tarif tertentu (PP 18/2021). Sulasi Rongiyati menyatakan bahwa meskipun implementasi pemberian hak diatas tanah HPL melalui perjanjian kepada pihak lain telah sesuai dengan peraturan perundang-undangan, namun karena kurangnya pengawasan pemerintah selaku pemegang HPL sebagai pemberi hak atas tanah mengakibatkan kerap terjadi penyimpangan atas perjanjian dalam hal larangan memindahtangankan hak atas tanah oleh pihak yang menandatangani perjanjian kepada pihak ketiga, dimana secara yuridis kedudukan pihak ketiga hanyalah pihak yang "menumpang”, sehingga beberapa kasus penggunaan tanah HPL menimbulkan sengketa di masyarakat. Sulasi Rongiyati berpendapat jika HPL akan tetap dipertahankan sebagai hak atas tanah maka harus diatur dalam undang-undang agar lebih memiliki kepastian hukum (Rongiyati, 2014:77-89). Hak milik atas satuan rumah susun tidak termasuk tanah bersama dengan segala bangunan diatasnya namun dibagi secara proporsional sehingga sertifikat hak milik atas satuan rumah susun sebagai hak yang terkuat dan terpenuh hanya atas satuan rumah susunnya yang dihuni saja (Roestamy, 2016:1-22).

Terlepas dari uraian singkat dari artikel-artikel tersebut diatas, penelitian ini sendiri membahas perlindungan konsumen terkait pemberian informasi yang jelas mengenai status hak atas tanah bersama apartemen oleh pelaku pembangunan kepada konsumen. Informasi merupakan sebuah faktor pertimbangan yang sangat penting diketahui konsumen agar konsumen dapat mengetahui kelebihan atau kekurangan suatu apartemen sebelum membelinya karena itu 2 (dua) masalah yang ingin dikemukakan dalam penelitian ini adalah:

1. Bagaimana perlindungan hukum terhadap pembeli apartemen terkait transparansi informasi status hak atas tanah bersama apartemen pada saat pemasaran dilakukan oleh pelaku pembangunan? 
2. Bagaimana penerapan asas kebebasan berkontrak dari pihak pembeli apartemen terkait kepastian status hak atas tanah bersama apartemen pada saat perjanjian pengikatan jual beli?

Tujuan penulisan yang pertama adalah untuk memberikan pengetahuan hukum kepada pembeli apartemen tentang bentuk perlindungan konsumen terkait kewajiban pelaku pembangunan dalam hal pemberian informasi secara akurat dan tersampaikan pada saat pemasaran. Tujuan yang kedua untuk memberikan pengetahuan kepada masyarakat dan para praktisi terkait materi yang perlu dimuat di dalam PPJB berupa informasi kepemilikan hak yang memberikan kepastian akan kebenaran status hak atas tanah bersama apartemen.

Penulis di dalam penelitian ini menggunakan pendekatan penelitian hukum normatif yaitu penelitian terhadap asas-asas hukum positif. Jenis data diperoleh dari bahan-bahan pustaka saja (data sekunder) terdiri dari bahan-bahan hukum premier, sekunder dan tersier yang berbasis pada peraturan perundangan yang berlaku, buku-buku kepustakakaan, dan tulisan ilmiah yang sebelumnya sudah ada. Studi dokumen serta metode analisis menggunakan analisis kualitatif. Sifat penelitiannya ialah preskriptif analitis.

\section{Pembahasan}

\section{A. Perlindungan Hukum Terhadap Pembeli Apartemen Terkait} Transparansi Informasi Status Hak Atas Tanah Bersama Apartemen Pada Saat Pemasaran

Kepastian hukum terkait hak atas tanah pertama kalinya sejak kemerdekaan Republik Indonesia diatur Undang-Undang Nomor 5 Tahun 1960 tentang Pokok-Pokok Agraria (UUPA) dimana macam-macam hak atas tanah diberikan kepada perorangan maupun secara bersama dengan orang-orang lainnya serta badan-badan hukum seperti ketentuan dalam Pasal 4 Ayat (1) jo Pasal 15 UUPA yang masing-masing hak atas tanah dibuktikan dengan sertipikat antara lain: Sertipikat Hak Milik (SHM), Sertipikat Hak Guna Usaha SHGU), Sertipikat Hak Guna Bangunan (SHGB), dan Sertipikat Hak Pakai (SHP). Sedangkan Hak 
Pengelolaan (HPL) diberikan oleh Negara kepada sesuatu Badan Penguasa (Pemerintah) untuk melaksanakan tugas pelayanannya sesuai peranannya masing-masing kepada rakyatnya sebagaimana ditegaskan oleh pakar ilmu agraria Boedi Harsono bahwa HPL merupakan sepenuhnya Hak Menguasai oleh Negara yaitu Bangsa Indonesia dalam penyelenggaraanya dilimpahkan kepada Pemda dan Masyarakat Hukum Adat, dengan syarat sepanjang diperlukan dan tidak bertentangan dengan kepentingan nasional yang merupakan tugas pembantuan dan bukan otonomi secara berdiri sendiri (Harsono, 2003:278).

Pasal 125-135 Undang-Undang Nomor 11 tahun 2020 tentang Cipta Kerja (UU Ciptaker) mengatur tentang pertanahan dimana Pemerintah Pusat membuat suatu badan yang disebut "badan bank tanah" yang berfungsi melaksanakan segala sesuatu tentang pertanahan mulai dari merencanakan, memperoleh, mengadakan, mengelola, memanfaatkan, dan mendistribusikan tanah-tanah. Tanah-tanah yang terdapat pada badan bank tanah semuanya diberikan HPL, dengan kewenangan untuk memberikan hak-hak HGU, HGB, dan HP di atas tanah HPL kepada pihak ketiga. Pasal-pasal yang terkait HPL dalam UU Ciptaker terdapat pada Pasal 136-142, sedangkan pengaturan Rumah Susun terdapat pada Pasal 143-145. Menurut Pasal 137 Ayat (1) UU Ciptaker, kewenangan terhadap tanah yang merupakan hak kekuasaan negara dapat diberikan HPL kepada Kantor-kantor Pemerintah Pusat dan Pemerintah Daerah, badan bank tanah, BUMN/BUMD, BHMN/BHMD, atau suatu badan hukum lain yang ditunjuk Pemerintah Pusat dalam pemanfaatan tanah untuk tujuan kepentingan memberikan pelayanan kepada masyarakat di wilayahnya atau nasional.

UU Ciptaker Pasal 145 menyebutkan gedung atau bangunan rumah susun dapat dibangun di atas 4 (empat) macam status hak atas tanah, yaitu:

1. HGB di atas tanah negara (HGB murni); atau

2. HGB di atas HPL; atau

3. Hak Pakai di atas tanah negara; atau

4. Hak Pakai di atas tanah HPL. 
Setelah UU Ciptaker dibentuk oleh Dewan Perwakilan Rakyat dengan persetujuan bersama Presiden, Presiden segera menetapkan Peraturan Pemerintah untuk menjalankan UU Ciptaker dan membuat Peraturan Presiden untuk melaksanakan Peraturan Pemerintah sebagaimana mestinya. Sampai saat penulisan ini sudah berlaku 45 Peraturan Pemerintah dan 4 Peraturan Presiden yang merupakan peraturan pelaksana UU Ciptaker, namun khusus yang berkaitan dengan apartemen/rumah susun dan status hak atas tanah antara lain:

1. Peraturan Pemerintah Nomor 12 Tahun 2021 tentang Perubahan Atas Peraturan Pemerintah Nomor 14 Tahun 2016 Tentang Penyelenggaraan Perumahan Dan Kawasan Permukiman (PP 12/2021);

2. Peraturan Pemerintah Nomor 13 Tahun 2021 tentang Penyelenggaran Rumah Susun (PP 13/2021); dan

3. Peraturan Pemerintah Nomor 18 Tahun 2021 tentang Hak Pengelolaan, Hak Atas Tanah, Satuan Rumah Susun dan Pendaftaran Tanah (PP 18/2021). Terkait dengan pemasaran, Undang-Undang Nomor 20 Tahun 2011 tentang Rumah Susun (UU 20/2011) dalam Pasal 42 menyatakan bahwa sebelum pembangunan rumah susun dilaksanakan, pelaku pembangunan diberikan kesempatan untuk memasarkan produk propertinya (pre-project selling), dengan persyaratan segala sesuatu yang dijanjikan oleh pelaku pembangunan dan/atau agen pemasaran mengikat sebagai Perjanjian Pengikatan Jual Beli (PPJB) bagi para pihak. PP 12/2021 Pasal 1 Angka 12 memberikan definisi pemasaran adalah kegiatan yang dilakukan pelaku pembangunan pada saat sebelum atau dalam proses sebelum penandatanganan PPJB yang terdiri dari kegiatan memperkenalkan, menawarkan, menentukan harga, dan menyebarluaskan informasi mengenai rumah susun. Selanjutnya, Pasal 22 Ayat (3) PP 12/2021 menyatakan pemasaran dilakukan melalui Sistem PPJB sebagaimana dimaksud di dalam Pasal 22A PP 12/2021, bahwa Sistem PPJB yang dimaksud terdiri atas:

1. Pemasaran; dan

2. PPJB.

Sebagaimana yang dimaksud dalam Pasal 1 Angka 11 PP 12/2021, PPJB adalah kesepakatan antara pelaku pembangunan dan konsumen untuk 
melakukan jual beli rumah susun yang dibuat di hadapan Notaris. Dari pengaturan di atas terkait jual beli ini, terdapat paling sedikitnya 3 (tiga) tahap yang harus dilalui oleh pelaku pembangunan, antara lain:

1. mengadakan kegiatan pemasaran;

2. memperoleh kesepakatan atau persetujuan pembelian dari konsumen yang dibuktikan dengan down payment atau booking fee; dan

3. Penandatanganan PPJB antara pihak pelaku pembangunan dan pembeli di hadapan Notaris.

Selain mengatur kegiatan pemasaran, PP 12/2021 di dalam Pasal 22 Ayat (5) mengatur bahwa Sistem PPJB (Perjanjian Pendahuluan Jual Beli) dapat dilakukan pengembang hanya jika telah memenuhi syarat clean and clear yaitu memperoleh suatu kepastian atas:

1. Kepastian dan kejelasan status kepemilikan tanah atau yang berhak;

2. Apa saja hal-hal yang diperjanjikan oleh pengembang;

3. Persetujuan untuk Bangunan Gedung (PBG) dari Pemda;

4. Ketersediaan fasilitas rumah susun seperti prasarana, sarana, dan utilitas umum; dan

5. pembangunan sudah tercapai minimal $20 \%$ (dua puluh persen).

Seperti dikemukakan sebelumnya, Pasal 22A PP 12/2021 menyatakan bahwa Sistem PPJB terdiri atas 2 komponen yaitu kegiatan pemasaran dan kegiatan PPJB. Artinya, sebelum kegiatan penandatanganan PPJB harus didahului oleh kegiatan pemasaran kepada konsumen. Ahli manajemen, Peter F. Drucker mengatakan bahwa Pemasaran adalah kegiatan pokok usaha itu sendiri dilihat dari hasil akhir, yaitu dari pandangan pelanggan (Drucker, 1969). Phillip Kotler mengatakan bahwa pemasaran adalah suatu proses bersifat sosial dimana seseorang dan/atau kelompok akhirnya memperoleh suatu benda atau jasa yang memang dibutuhkan dan diinginkan dengan cara kegiatan yang menciptakan/memproduksi, memberikan penawaran dan secara bebas mempertukarkan produk yang bernilai dengan pihak lain dengan suatu imbalan atau tarif tertentu (Kotler, 1997). John William Stanton berpendapat tentang kegiatan pemasaran yaitu suatu sistem yang mewakili seluruh kegiatan-kegiatan 
untuk pengembangan usaha dengan cara melalui perencanaan, penentuan harga, promosi dan penyaluran barang dan jasa yang dapat memenuhi kebutuhan pembeli yang sudah ada maupun pembeli yang akan ada (Stanton, 1994). Jika digabungkan pendapat para ahli di atas dapat ditarik kesimpulan bahwa pemasaran adalah proses peralihan suatu barang/jasa dari produsen kepada konsumen dengan cara sedemikian rupa dengan imbalan tertentu untuk memenuhi kebutuhan pembeli, yang tingkat keberhasilan pemasaran diukur dari kepuasan konsumen. Namun pada prakteknya, pelaku pembangunan yang profit oriented memanfaatkan prilaku konsumen yang mudah tergiur dengan promosi/iklan dan mengabaikan prinsip kepuasan pelanggan (Lukitaningsih, 2013:21-35).

Sebagai konsumen berhak mendapatkan perlindungan hukum dalam hal transparansi informasi sebagai bahan pertimbangan sebelum memutuskan untuk membeli atau tidak. Pasal 22B Ayat (2) menyatakan bahwa pada saat kegiatan pemasaran rumah susun wajib mencantumkan informasi yang jelas dan benar mulai dari perencanaan, kondisi fisik yang ada, dan status kepemilikan tanah.

Pasal 22C PP 12/2021 juga menyatakan pelaku pembangunan yang melakukan pemasaran harus memiliki paling sedikit kepastian peruntukan ruang, kepastian hak atas tanah, kepastian status penguasaan, perizinan pembagunan, dan jaminan atas pembangunan dari lembaga penjamin dengan disertakan masing-masing pembuktian berupa surat keterangan terkait rencana tata ruang kabupaten/kota yang telah disetujui Pemerintah Daerah, sertipikat hak atas tanah atas nama pelaku pembangunan atau pemilik tanah yang bekerja sama atau sertipikat hak atas tanah lainnya yaitu SHM, SHGB, SHP dan menjelaskan mengenai bukti penguasaan yang akan diterbitkan atas nama pembeli apartemen berupa sertipikat hak milik satuan rumah susun (SHMSRS) atau sertipikat kepemilikan bangunan gedung satuan rumah susun (SKBGSRS), surat PBG, dan surat dukungan yang dikeluarkan oleh bank atau lembaga keuangan lain. Selanjutnya, pasa ini menyatakan bahwa pengawasan terhadap persyaratan kegiatan Pemasaran dilakukan oleh perangkat yang terdapat di pemerintahan 
daerah yang membidangi Perumahan dan Kawasan Pemukiman Pemerintah Daerah kabupaten/kota atau Provinsi DKI Jakarta.

Selanjutnya, Pasal 22D Ayat (1) menambahkan lebih terperinci informasi apa saja yang perlu disampaikan pada saat kegiatan pemasaran yaitu informasi terkait perencanaan pembangunan, kepemilikan tanah, dan spesifikasi rumah susun, sekaligus fasilitas yang terdapat di rumah susun wajib disosialisasikan kepada masyarakat publik dengan mencantumkan hal-hal berikut:

1. nomor surat keterangan terkait rencana tata ruang kabupaten/kota yang telah disetujui Pemerintah Daerah;

2. nomor sertipikat hak atas tanah dan penyebutan salah satu dari nama pengembang atau pemilik tanah yang bekerja sama dengan pengembang atau sertipikat hak atas tanah lainnya;

3. surat dukungan bank atau lembaga keuangan lain yang menyebutkan jumlah dana yang siap didukung oleh bank;

4. nomor dan tanggal pengesahan dari kementerian hukum dan hak asasi manusia untuk pelaku pembangunan yang berbentuk perusahaan berbadan hukum, termasuk juga nomor dan tanggal Anggaran Dasar dan perubahan terakhir Anggaran Dasar atau jika bukan bentuk perseroan, maka nomor identitas untuk pelaku pembangunan orang perseorangan;

5. nomor dan tanggal penerbitan surat PBG;

6. perencanaan denah/tapak tempat pembangunan rumah susun;

7. spesifikasi dan denah untuk masing-masing bangunan dan satuan rumah susun lengkap dengan berbagai type atau gambar bangunan yang dipotong secara vertikal yang memperlihatkan isi atau bagian dalam bangunan dan denah dari satuan rumah susun;

8. harga jual satuan rumah susun;

9. informasi fasilitas-fasilitas rumah susun berikut prasarana, sarana, dan utilitas umum; dan

10. informasi bagian bersama, benda bersama, dan tanah bersama di seputar pembangunan rumah susun apakah milik dari seorang atau beberapa orang/badan hukum. 
Kemudian Pasal 22D Ayat (2) menyatakan bahwa dalam hal sertipikat kepemilikan atau pemegang hak atas tanah bersama atas nama selain pelaku pembangunan, maka harus mencantumkan nomor dan tanggal perjanjian kerjasama serta jangka waktu perpanjangan yang terdapat dalam perjanjian antara pemegang hak atas tanah lainnya (hak milik atau hak pengelolaan) dengan pemegang hak guna bangunan rumah susun. Lalu, Pasal 22D Ayat (3) selanjutnya mengatur agar informasi terkait rumah susun tersebut dapat disebarluaskan melalui media cetak seperti brosur, selebaran, spanduk, dan/atau iklan di koran atau majalah dan/atau media elektronik.

Pasal-pasal UU Ciptaker yang telah disebutkan diatas sejalan dengan Undang-Undang Nomor 8 Tahun 1999 tentang Perlindungan Konsumen (UU 8/1999) yang bertujuan untuk menciptakan suatu payung hukum yang menjamin adanya kepastian hukum untuk memberikan perlindungan kepada konsumen. Pasal 4 UU 8/1999 menyatakan hak-hak konsumen antara lain adalah memilih serta mendapatkan barang/dan atau jasa sesuai dengan kondisi serta jaminan yang dijanjikan serta berhak atas informasi yang benar, jelas, dan jujur mengenai kondisi dan jaminan tersebut. Selanjutnya, jika barang dan/atau jasa yang diterima tidak sesuai dengan perjanjian atau tidak sebagaimana mestinya, konsumen berhak untuk mendapatkan kompensasi, ganti rugi dan/atau penggantian. Hak-hak konsumen tersebut merupakan kewajiban pelaku usaha yang ternyatakan dalam Pasal 7 UU 8/1999 untuk memberikan informasi yang benar, jelas, dan jujur mengenai kondisi dan jaminan. Selanjutnya menurut Pasal 45 UU 8/1999 setiap konsumen yang dirugikan dapat menggugat pelaku usaha melalui lembaga yang bertugas menyelesaikan sengketa antara konsumen dan pelaku usaha atau melalui peradilan yang berada di lingkungan peradilan umum berdasarkan pilihan sukarela para pihak yang bersengketa. Menurut Sahlevi Dwinanda, proses penyelesaian sengketa melalui Badan Penyelesaian Sengketa Konsumen (BPSK) lebih efektif daripada pengadilan negeri dilihat dari waktu penyelesaian sengketa, proses yang sederhana dan mudah, tidak ada biaya, dan eksekusi ganti rugi berupa perjanjian para pihak dan dikuatkan dalam Putusan BPSK (Dwinanda, 2017:110-138). 


\section{B. Asas Kebebasan Berkontrak (Contracts-Vrijheid) Dalam Perjanjian Pengikatan Jual Beli}

Jika setelah pelaku pembangunan melakukan pemasaran, konsumen ingin membeli apartemen, maka seharusnya kehendak pihak-pihak dituangkan ke dalam akta PPJB yang dibuat dalam bentuk akta autentik berdasarkan asas kebebasan berkontrak. Pengertian akta adalah suatu bentuk tulisan yang dibuat dengan sengaja untuk dijadikan alat bukti tentang suatu perbuatan hukum (Subekti, 2004:25). Akta autentik harus dibuat dalam bentuk yang ditentukan menurut undang-undang dibuat oleh atau di hadapan pejabat umum yang berwewenang di tempat dibuatnya akta (KUHPer:1868). Mengingat asas kebebasan berkontrak, dalam hal materi atau isi PPJB sudah terlebih dahulu disiapkan oleh pelaku, maka informasi terkait materi atau isi dari pasal-pasal PPJB wajib dijelaskan pelaku pembangunan pada saat pemasaran, hal ini sesuai dengan Pasal 22E PP 12/2021.

Pasal 22F PP 12/2021 pun memperbolehkan pelaku pembangunan untuk menarik pembayaran dari calon pembeli, antara lain berupa Down Payment atau Booking Fee, yang merupakan bagian dan termasuk pembayaran rumah susun. Saat menerima pembayaran, pelaku pembangunan harus menyampaikan informasi perihal jadwal lengkap antara lain jadwal pembangunan, tanda-tangan PPJB, tanda tangan Akta Jual Beli (AJB), dan kapan dilakukan serah terima apartemen.

Dalam hal pelaku pembangunan lalai memenuhi jadwal tersebut, menurut Pasal 22H PP 12/2021 calon pembeli dapat membatalkan pembelian rumah susun dan pembayaran yang sudah diterima wajib dikembalikan sepenuhnya oleh pelaku pembangunan kepada calon pembeli. Namun dalam hal kelalaian bukan disebabkan dari pelaku pembangunan, maka pelaku pembangunan dapat memotong pengembalian pembayaran kepada calon pembeli sedikitnya $20 \%$ (dua puluh persen) ditambah dengan biaya pajak yang telah diperhitungkan.

Menurut Pasal 22I, PPJB boleh dilakukan setelah pelaku pembangunan memenuhi persyaratan kepastian atas status kepemilikan tanah, hal yang diperjanjikan, PBG, ketersediaan prasarana, sarana, dan utilitas umum, dan 
keterbangunan paling sedikit 20\%. Dalam hal status kepemilikan tanah wajib dibuktikan dengan sertipikat hak atas tanah yang diperlihatkan kepada calon pembeli pada saat penandatanganan PPJB.

Materi yang menjadi isi/muatan dari PPJB menurut Pasal 22J paling sedikit memuat 11 (sebelas) hal, yaitu:

1. identitas para pihak,

2. uraian objek PPJB,

3. harga rumah dan tata cara pembayaran,

4. jaminan pelaku pembangunan,

5. hak dan kewajiban para pihak,

6. waktu serah terima bangunan,

7. pemeliharaan bangunan,

8. penggunaan bangunan,

9. pengalihan hak,

10. pembatalan dan berakhirnya PPJB, dan

11. penyelesaian sengketa.

PPJB adalah perjanjian yang mengikat pihak penjual dan pihak pembeli untuk melaksanakan jual beli. Menurut Subekti, jual beli adalah menyerahkan hak milik atas suatu barang dan pihak yang lain untuk membayar harga yang telah dijanjikan (Subekti, 2004:79). Sedangkan syarat-syarat sahnya suatu perjanjian menurut ketentuan Pasal 1320 Kitab Undang-Undang Hukum Perdata (KUHPerdata) adalah sebagai berikut :

1. Adanya persetujuan kehendak antara pihak-pihak yang membuat perjanjian (consensus). Persetujuan kehendak itu sifatnya bebas (Contracts-Vrijheid), artinya tidak ada paksaan (dwang), kekhilafan (dwaling) maupun penipuan (bedrog).

2. Ada kecakapan pihak-pihak untuk membuat perjanjian (capacity). Orang disebut cakap melakukan perbuatan hukum apabila sudah dewasa dan tidak ditaruh di bawah pengampuan.

3. Ada suatu hal tertentu (object). Suatu hal tertentu merupakan pokok perjanjian, objek perjanjian, prestasi yang wajib dipenuhi. 
4. Ada suatu sebab yang halal (legal cause). Yang dimaksud dengan cause yang halal dalam Pasal 1320 KUHPerdata itu bukan berarti sebab yang mendorong orang membuat perjanjian, melainkan sebab dalam arti "isi perjanjian itu sendiri” yang menggambarkan tujuan yang akan dicapai oleh pihak-pihak.

Syarat pertama dan kedua Pasal 1320 KUHPerdata disebut syarat Subjektif karena melekat pada diri orang yang menjadi subjek perjanjian, maka jika syarat ini tidak dipenuhi, perjanjian dapat dibatalkan (vernietigbar). Tetapi jika tidak dimintakan pembatalan kepada Hakim, perjanjian itu tetap mengikat pihakpihak, walaupun diancam pembatalan sebelum lampau waktu lima tahun (Pasal 1454 KUHPerdata). Syarat ketiga dan keempat Pasal 1320 KUHPerdata disebut syarat Objektif, karena mengenai sesuatu yang menjadi objek perjanjian. Jika syarat ini tidak dipenuhi, perjanjian batal (nietig, void).

Menurut Herlien Budiono, suatu perjanjian terdiri dari beberapa bagian, yaitu bagian essentialia, bagian naturalia dan bagian accidentalia. Bagian essentialia merupakan bagian dari suatu perjanjian yang harus ada, sehingga apabila bagian tersebut tidak ada, maka perjanjian tersebut bukanlah perjanjian yang dimaksud oleh pihak-pihak (Budiono, 2009:57). Dalam materi PPJB yang wajib dimuat oleh Pasal 22J PP 12/2021, yang termasuk di dalam bagian essentialia adalah:

1. identitas para pihak,

2. uraian objek PPJB, dan

3. harga rumah.

Bagian naturalia adalah bagian dari suatu perjanjian yang menurut sifatnya dianggap ada tanpa perlu diperjanjikan secara khusus oleh para pihak (Budiono, 2009:70). Bagian naturalia dapat kita temukan di dalam ketentuan peraturan perundang-undangan yang bersifat mengatur. Sehingga apabila para pihak tidak mengatur, maka ketentuan peraturan-perundang-undanganlah yang akan berlaku. Dalam materi PPJB yang wajib dimuat oleh Pasal 22J PP 12/2021, yang termasuk di dalam bagian naturalia PPJB adalah:

1. hak dan kewajiban para pihak, 
2. jaminan pelaku pembangunan,

3. pemeliharaan bangunan,

4. penggunaan bangunan, dan

5. pengalihan hak.

Bagian accidentalia adalah bagian dari perjanjian yang merupakan ketentuan yang diperjanjikan secara khusus oleh para pihak yang tidak termasuk bagian essentialia maupun naturalia dalam PPJB (Budiono, 2010: 71). Dalam materi PPJB yang wajib dimuat oleh Pasal 22J PP 12/2021, yang termasuk di dalam bagian naturalia PPJB adalah:

1. tata cara pembayaran,

2. waktu serah terima bangunan,

3. pembatalan dan berakhirnya PPJB, dan

4. penyelesaian sengketa.

Jika dihubungkan antara Pasal 22I Ayat (3) PP 12/2021 bahwa status kepemilikan tanah bersama apartemen harus dibuktikan dengan sertipikat hak atas tanah yang diperlihatkan kepada calon pembeli pada saat penandatanganan PPJB, dengan Pasal 22J PP 12/2021 bahwa salah satu materi yang wajib dimuat dalam PPJB adalah "uraian objek PPJB", maka PPJB yang merupakan perjanjian formil dalam bentuk akta notaris agar memberikan perlindungan hukum kepada pembeli apartemen dalam hal kebenaran informasi yang disampaikan oleh pelaku pembangunan pada saat pemasaran, mencantumkan isi dari sertipikat hak atas tanah bersama apartemen antara lain: nomor sertipikat, pemegang hak, status hak atas tanah, dan informasi penting lainnya di dalam bagian essentiali dari PPJB bersangkutan.

Informasi tentang status hak atas tanah bersama yang satuan rumah susun ditawarkan kepada pembeli: HGB di atas tanah negara, HGB di atas HPL, Hak Pakai di atas tanah negara, atau Hak Pakai di atas tanah HPL merupakan bagian dari syarat "sebab yang halal" dari Pasal 1320 KUHPerdata dalam arti "isi perjanjian itu sendiri” yaitu bagian essentiali dari PPJB atau disebut syarat Objektif, karena mengenai sesuatu yang menjadi objek perjanjian. Jika syarat ini tidak dipenuhi, perjanjian menjadi batal (nietig, void). 
Selain kebatalan PPJB yang disebabkan karena isi dari perjanjian yang tidak sesuai dengan apa yang menjadi kehendak pembeli apartemen, Pasal 110 UU 20/2011 memberikan hukuman pidana penjara maksimal 4 (empat) tahun atau denda Rp 4 milyar bagi pelaku pembangunan yang membuat PPJB yang tidak sesuai dengan yang dipasarkan atau belum memenuhi persyaratan clean and clear seperti yang telah diuraikan diatas.

\section{Penutup}

\section{A. Kesimpulan}

1. Bagi pembeli apartemen, informasi status hak atas tanah bersama apartemen menjadi penting diketahui dalam hal perpanjangan HGB tanah bersama apartemen pada saat jatuh tempo, karena di antara berbagai status tanah bersama (hak milik, tanah negara, dan hak pengelolaan) yang diatasnya dibangun apartemen terdapat perbedaan signifikan untuk persyaratan dan biaya perpanjangan HGB. HGB murni dapat diperpanjang atau diperbarui jika memenuhi syarat bahwa tanah masih dimanfaatkan dengan baik sesuai dengan keadaan, sifat, dan tujuan semula pemberian HGB diatas tanah negara. Sedangkan HGB di atas HPL dapat diperpanjang selain harus memenuhi syarat-syarat tetapi juga harus mendapat persetujuan dari pemegang HPL, dan HGB di atas tanah hak milik cukup berdasarkan kesepakatan antara pemegang hak guna bangunan dengan pemegang hak milik. Perbedaan dalam hal HGB diatas hak milik, tanah negara, dan hak pengelolaan yang paling sulit memperoleh perpanjangan maupun pembaruan adalah HGB di atas hak pengelolaan, karena itulah informasi yang jelas terkait status kepemilikan hak atas tanah bersama apartemen wajib diberitahukan oleh pelaku pembangunan pada saat melakukan kegiatan pemasaran sehingga calon pembeli dapat bebas memilih untuk membeli tidaknya apartemen berdasarkan informasi yang didapatkan pada saat pemasaran terkait kewajiban pelaku pembangunan yang diatur dalam PP 12/2021 dan UU 8/1999. 
2. PPJB yang merupakan perjanjian formil dalam bentuk akta notaris sepatutnya berdasarkan asas kebebasan berkontrak guna memberikan perlindungan hukum bagi pembeli apartemen dalam hal kebenaran informasi yang disampaikan oleh pelaku pembangunan pada saat pemasaran, dengan cara mencantumkan isi dari sertipikat hak atas tanah bersama apartemen antara lain: nomor sertipikat, pemegang hak, status hak atas tanah, dan informasi penting lainnya di dalam bagian essentiali dari PPJB bersangkutan. Bagian essentiali dari PPJB harus menyatakan persetujuan dari kehendak bebas pihak pembeli dan pihak penjual sebagai salah satu implementasi syarat sahnya perjanjian di dalam Pasal 1320 KUHPerdata (syarat Subjektif) dan keterangan dari suatu objek tertentu yaitu status hak atas tanah yang diatasnya dibangun apartemen (syarat Objektif). Hal ini diperlukan agar terjadi keseimbangan kedudukan antara pelaku pembangunan dan pembeli apartemen.

\section{B. Saran}

1. Dalam penelitian ini, disarankan kepada pemerintah untuk membentuk badan pengawas terhadap pelaku pembangunan rumah susun yang bertugas menerima laporan dari masyarakat dan menindaklanjuti terhadap penyimpangan kegiatan pemasaran dan pelaksanaan PPJB yang dilakukan pelaku pembangunan. Badan pengawas tersebut juga dapat mengadakan pemeriksaan berkala (audit) setelah rumah susun terjual 25\%, 50\%, 75\% dan 100\%. Saran kepada badan legislatif agar dapat mengatur pemberian sanksi kepada pelaku pembangunan terhadap kelalaian memberikan informasi pada saat kegiatan pemasaran.

2. Berdasarkan uraian yang disampaikan di atas tentang isi materi yang wajib dimuat dalam PPJB dan kewajiban memperlihatkan sertipikat hak atas tanah bersama apartemen, untuk penerapannya agar badan legislatif bersama-sama dengan pemerintah dapat merancang suatu format baku PPJB yang dapat memuat status hak atas tanah bersama 
sebagai lampiran terkait petunjuk materi muatan PPJB sepanjang tidak bertentangan dengan peraturan perundangan, yang merupakan bagian tidak terpisahkan dari PP 12/2021.

\section{Daftar Pustaka}

Bagus. (2020). Backlog Perumahan Jadi Peluang Kebangkitan Sektor Properti. Diambil 26 Agustus 2021, dari Bimata ID website: https://bimata.id/2020/12/backlog-perumahan-jadi-peluang-kebangkitansek-tor-properti/

Budiono, H. (2010). Ajaran Umum Hukum Perjanjian dan Penerapannya di Bidang Kenotariatan. Bandung: Citra Aditya Bakti.

Drucker, P. F. (1969). The Practice of Management. New York: Harper \& Row.

Dwinanda, S. (2017). Perbandingan Efektivitas Penyelesaian Sengketa Konsumen Pada Pengadilan. Reformasi Hukum, XXI(1). https://doi.org/10.46257/jrh.v21i1.18

Dwiwanto, D. (2021). Mengenal HGB di Atas HPL | Konsumen Wajib Memahami Sebelum Membeli Apartemen.

Fadli, A. (2021). Pindah Rumah di Perkotaan, Siap-siap Hadapi 6 Masalah Berikut Ini. Diambil 26 Agustus 2021, dari Kompas website: https://www.kompas.com/properti/read/2021/04/22/11320 6321/pindahrumah-di-perkotaan-siap-siap-hadapi-6-masalah-berikut-ini?page= all\#page 2

Harsono, B. (2003). Hukum Agraria Indonesia: Sejarah Pembentukan UUPA, Isi dan Pelaksanaannya. Jakarta: Djambatan.

Kotler, P. (1997). Marketing Management: Analysis, Planning, and Control, 9th $E d$. London: Prentice-Hall, International.Inc.

Lukitaningsih, A. (2013). Perkembangan Konsep Pemasaran: Implementasi Dan Implikasinya. Jurnal Maksipreneur, III(1). Diambil dari https://ejournal.up45.ac.id/index.php/maksipreneur/article/view/85

Petriella, Y. (2020a). Apersi: Data Backlog Perumahan Tak Seragam. 
Petriella, Y. (2020b). Backlog Perumahan, Pengamat: Harus Ada Pembagian Tugas yang Jelas. Diambil 26 Agustus 2021, dari Ekonomi Bisnis website: https://ekonomi.bisnis.com/read/20200714/47/1265942/backlogperumahan-pengamat-harus-ada-pembagian-tugas-yang-jelas

Pinhome. (2021). Apa Itu Backlog? - Kamus Istilah Properti Pinhome. Diambil 26 Agustus 2021, dari Pinhome.id website: https://www.pinhome.id/ kamus-istilah-properti/backlog/

Republik Indonesia. Peraturan Pemerintah Nomor 12 Tahun 2021 tentang Perubahan atas Peraturan Pemerintah Nomor 14 Tahun 2016 tentang Penyelenggaraan Perumahan dan Kawasan Permukiman.

Republik Indonesia. Peraturan Pemerintah Nomor 13 Tahun 2021 tentang Penyelenggaraan Rumah Susun.

Republik Indonesia. Peraturan Pemerintah Nomor 18 Tahun 2021 tentang Hak Pengelolaan, Hak Atas Tanah, Satuan Rumah Susun, dan Pendaftaran Tanah.

Republik Indonesia. Undang-Undang Nomor 11 Tahun 2020 Tentang Cipta Kerja.

Republik Indonesia. Undang-Undang Nomor 20 Tahun 2011 tentang Rumah Susun.

Republik Indonesia. Undang-Undang Nomor 5 Tahun 1960 tentang Pokokpokok Agraria.

Republik Indonesia. Undang-Undang Nomor 8 Tahun 1999 tentang Perlindungan Konsumen.

Roestamy, M. (2016). Paradigma Hak Kebendaan Kepemilikan Sarusun Yang Dibangun Pada Lahan Hak Guna Bangunan. Jurnal Hukum De 'rechtsstaat, 2(1). https://doi.org/10.30997/jhd.v2i1.679

Rongiyati, S. (2014). Pemanfaatan Hak Pengelolaan Atas Tanah Oleh Pihak Ketiga. Negara Hukum: Membangun Hukum Untuk Keadilan dan Kesejahteraan, 5(1). https://doi.org/10.22212/jnh.v5i1.212

Stanton, J. W. (1994). Fundamentals of Marketing, 10th Ed. Tokyo: Kogakusha, McGraw-Hill Book Company. 
Subekti, R. (2004). Hukum Perjanjian. Jakarta: Intermasa.

Zamil, Y. S. (2017). Perlindungan Hukum Pembeli Apartemen Atau Rumah Susun Di Atas Tanah Hak Pengelolaan. Arena Hukum, 10(3). https://doi.org/10.21776/ub.arenahukum.2017.01003.6 